\title{
Drummond: uma conversão gradual ao Modernismo
}

\author{
Thaís Isabel Castro \\ Universidade Federal de Minas Gerais
}

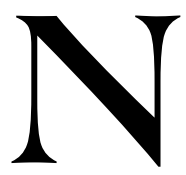

os estudos interpretativos da obra de Drummond há um consenso de que o poeta faz parte da geração de 1930, isto é, não é visto como participante da fase heróica do Modernismo Brasileiro, em que a Semana de Arte Moderna de 1922 se tornou um marco, e, conseqüentemente, seu primeiro livro, Alguma poesia (1930), é interpretado como uma superação das conquistas formais dessa primeira fase. Dito de outra maneira, o que se tem cristalizado pela historiografia e pela crítica literária brasileira é que Drummond não passou por uma evolução (como é apontada em Manuel Bandeira e Mário de Andrade), como se fosse, portanto, um modernista nato. A demora na publicação de seu primeiro livro tende a colaborar com isso, consagrando-lhe a influência na produção poética posterior a 1920.

Em estudo sobre o Modernismo Brasileiro, Assis Brasil afirma que "a fase experimental e de amadurecimento do modernismo, sem dúvida, termina com Drummond". Porém, essa afirmação pode ser problematizada por outra do mesmo crítico:

...É evidente que ao estrear em 1930 (Alguma poesia), Carlos Drummond selecionara, entre seus poemas, aqueles que mais de perto "falavam" à corrente nova, deixando no esquecimento ou perdidos em folhas de alguns jornais, trabalhos de sua adolescência ou juventude que ainda estariam comprometidos com uma literatura tradicional. Mas esta fase interessa mais ao pesquisador da história literária e não tanto ao crítico. Que vê na obra de estréia aquilo que o poeta sedimentou e achou como válido para seu aparecimento em livro.

${ }^{1}$ BRASIL, 1976, p.101-102. 
É bastante questionável que essa fase inicial interesse mais "ao pesquisador da história literária e não tanto ao crítico", uma vez que constatamos que a produção dessa fase é bastante numerosa e nem toda ela está comprometida com a literatura tradicional. Convém lembrar que, já em 1923, o poeta escreveu poemas que passaram a constar em sua obra definitiva e foram, como alguns dos inéditos que aqui serão apresentados, publicados em jornais e revistas dos anos 20, de que são exemplos os poemas "Nota social" e "Coração numeroso", a que se seguiram, em 1924, "Construção", "Política", "Sentimental" e o célebre "No meio do caminho". E mesmo os textos comprometidos com a literatura tradicional têm sua importância, uma vez que demonstram que a adoção da estética modernista por parte de Drummond significou um desafio literário na construção de sua poética particularíssima. Concordamos com John Gledson que, em relação aos primeiros escritos do jovem poeta, no livro Poesia e poética de Drummond, afirma que o que se constata é a subestimação da obra juvenil de Drummond, bastante reveladora de um momento decisivo na trajetória do poeta: o da sua conversão gradual ao modernismo, tateando pelas diversas possibilidades estéticas, o que demonstra que a sua inserção no movimento modernista não foi natural, mas uma escolha consciente após um longo período de experimentalismos, que não podem ser associados diretamente às vanguardas modernistas.

No livro A literatura no Brasil, organizado por Afrânio Coutinho, em capítulo intitulado "O Modernismo na poesia", Péricles Eugênio da Silva Ramos, situa Drummond, curiosamente, dentro de um item intitulado "Fase de ruptura - a geração de 1922 e evolução posterior", portanto, dentro da primeira fase do modernismo. Ramos faz essa classificação porque situa Drummond no grupo mineiro de A Revista, constatando em relação ao poeta que "a história de sua poesia é a história de uma longa construção". O comentário é interessante e apropriado para esse artigo uma vez que é justamente dessa "longa construção", descartada dos estudos sobre a poética Drummondiana, e que poderia contribuir para uma visão mais ampla do lugar ocupado pelo poeta dentro da poesia brasileira, que trataremos mais detidamente de agora em diante.

Além de textos enviados por cartas a amigos (ressaltamos aqui um caderno manuscrito com sessenta e cinco poemas enviado por Drummond em maio de 1926 a seu principal interlocutor: Mário de Andrade), dentre os escritos inéditos de Drummond, destacam-se poemas, poemas-emprosa (em maior número), aforismos, crônicas, críticas e alguns ensaios 
literários, além de outros poucos gêneros, escritos e publicados em jornais e revistas da década de 20. Drummond publicou, com maior constância, no período de 1921 a 1930, nos jornais Diário de Minas (DM: 1921-1929) e Minas Gerais (MG: 1930); e nas revistas cariocas Ilustração Brasileira (IB: 1922-1926) e Para Todos (PT: 1922-1927).

O Diário de Minas era o jornal oficial do Partido Republicano Mineiro (PRM) que representava a oligarquia rural que, nos anos 20, dominava a política do estado de Minas Gerais. O jornal não tinha muita repercussão. Drummond, em entrevista a Maria Zilda Cury, assim se refere a esse jornal: “...o jornal não tinha nenhuma circulação, era um jornal inexistente, e o governo não ligava. ...No Diário de Minas, então, era o seguinte: o governo não ligava absolutamente para o Modernismo. A gente praticava as maiores bobeiras ou as maiores molecagens... ${ }^{2} \mathrm{Na}$ verdade, essas "bobeiras ou molecagens" apontavam para um quadro de insatisfação geral com a literatura produzida na época, como Drummond depõe:

Nós não estávamos satisfeitos com o que havia lá. Não só em Minas como no Brasil, a literatura tinha sofrido um certo declínio. E pegando os livros publicados em 1920, 21 e 22, verificamos que não havia nada de novo, realmente, no Brasil. Por exemplo, na poesia, eu acho isso muito mais significativo. Os grandes poetas brasileiros da geração parnasiana praticamente tinham acabado. [...] Então, realmente, é como se diz: estava vaga a chefia ou a direção da poesia brasileira. Quando o eixo então se deslocou para São Paulo com Mário de Andrade, Oswald de Andrade, Menotti Del Picchia, Sérgio Milliet, eles passaram a ocupar para os moços um lugar que estava vazio. ${ }^{3}$

Antes da atenção de Drummond ser desviada para São Paulo e pelo que lá se fazia de novo, o que só veio a acontecer efetivamente em abril de 1924, quando o grupo paulista - Mário e Oswald de Andrade, Tarsila do Amaral, acompanhados do poeta Blaise Cendrars - esteve em Belo Horizonte, Drummond já publicava regularmente em alguns periódicos.

Foi certamente um período conturbado esse em que "estava vaga a chefia ou a direção da poesia brasileira", um momento de impasse, de transição, em que a herança da tradição se misturava às tendências inovadoras que irromperiam no Modernismo. Essa transição é nítida em,

\footnotetext{
${ }^{2}$ CURY, 1998, p.150-152.

${ }^{3}$ CURY, 1998, p. 143.
} 
por exemplo, Mário de Andrade e Manuel Bandeira. Drummond, embora não pertença à geração desses escritores, já no início dos anos 20, publicava em jornais e revistas poemas que oscilavam entre tendências simbolistas e neo-simbolistas e uma dicção mais inovadora.

Drummond estreou no jornal Diário de Minas em 2/12/1921 com a publicação de dois poemas:

\section{O poema dos amantes que envelheceram com o último beijo}

São duas sombras... Não são mais do que duas sombras, muito esguias e muito brancas...

Nas bocas enrugadas, dorme a ressonância do último beijo, a florir, em desespero, no último espasmo...

Sobreviveram a volúpia, - mas desencantados... Que é do antigo desejo? Que é do anseio anterior? Deslembraram o anseio, esqueceram o desejo.

$\mathrm{Na}$ ironia de um sorriso, as bocas enrugadas revelam a ausência dos dentes...

São duas máscaras... Não são mais que duas máscaras, muito tristes, muito brancas...

\section{O poema da mulher que não mais se refletia no espelho}

Nos jardins vestidos de névoa, as flores pendem melancolicamente, e as estátuas sussurram um cântico de lassitude e de abandono...

Nos jardins vestidos de névoa, anda vagando um vulto misterioso de mulher magra...

Seus passos não acordam nenhum rumor, seu corpo não gera nenhuma sombra, nos jardins vestidos de névoa...

Sua alma é como um crepúsculo doloroso, que se esbate e desaparece...

Foge dos espelhos, que já não lhe refletem as formas longas e frias, fogo de si mesmo foge de tudo, nos jardins vestidos de névoa...

A descrição de personagens e ambientes decadentes, misteriosos, como a ambientação nos "jardins vestidos de névoa"; a exploração da cor branca e variantes (como névoa, por exemplo) notadamente como signo de mistério, sugerindo diafaneidades, lugar comum entre os simbolistas; o abstracionismo antimaterialista; todas essas características geralmente expressas através do recurso estilístico da repetição de palavra ou idéia, e que encontramos nesses textos de Drummond, marcaram profundamente a estética simbolista. Não foram poucos os textos publicados que 
mantiveram esse tom. Proliferam nos jornais e revistas do início dos anos 20 poemas-em-prosa em que reaparecem as paisagens desoladas, vagas, indefinidas; em que os seres são tão evanescentes quanto a paisagem descrita; e em que permanece a predileção pela cor branca como símbolo do etéreo, do misterioso, do invisível.

No poema "Música" (DM,15/05/1923), o tom melancólico se faz obsessivamente presente através da composição do ambiente: "Em torno a mim, tudo se faz sombra, imprecisão, melancolia crepuscular [...] idealizo edens de sombra e de luar..." Também em "Mãos" (DM, 18/05/1923), observam-se vestígios da estética simbolista: "Persegue-me a saudade de duas mãos que eu nunca vi, e que se espalmaram, afiladas e brancas sobre o meu destino. Vejo-as em toda parte, na fumaça trêmula deste cigarro, no ar envelhecido da tarde, na água, no sonho, na vida...Tão brancas... É como se guardassem a alma do branco..."

Outro aspecto significativo quando falamos da poesia simbolista, é certamente a sua associação com a música. Nos poemas escritos por Drummond nessa fase inicial, encontramos freqüentes alusões a aspectos sonoros, criando uma espécie de ambiente tonal que envolve os seres e as coisas. Em "Música" (DM, 15/05/1923), em que a associação poesia e música aparece já no título, temos a seguinte descrição: "Quedo-me ouvindo a música de um piano sentimental, que vem do outro lado da rua... A música penetra-me o eu, lacera-me as carnes, arranca-me lágrimas, invade-me a alma... Cá dentro, há uma sonora dispersão de ritmos magoados." Já em "A rua solitária” (DM, 25/08/1923), o próprio silêncio se encontra associado a sons: "O silêncio da noite, nesta rua, é profundo e cheio de ritmos. É um silêncio dentro do qual giram todos os acordes abafados, todas as melodias ocultas, numa palpitação que se confunde com as estrelas".

Ainda no rol das convenções simbolistas e neo-simbolistas, a impressão do sonhar acordado; da confusão entre real e ideal, ou irreal, aparece em alguns dos poemas-em-prosa de Drummond. No já citado "Música", temos:

...Ponho-me a sonhar, que eu sempre sonho quando me embriago de tristeza... Lembra-me o que fui em eras distantes, ao sul de outras terras, evoco paisagens nunca vistas, idealizo edens de sombra e de luar... Viajo... Adoro a vadiação dos nômades, dos sem pátria. E beijo mulheres únicas, mulheres fadas, por essa longa peregrinação da música estonteante. 
Mas o piano emudece. Sinto a vertigem de um Ícaro, caindo de bruços na realidade. E mais desgraçado do que nunca, porque a realidade é a minha cruz de Cristo: vai redobrando de peso passo-apasso...

Nos poemas-em-prosa publicados, encontramos desde recriações de ambientes crepusculares e melancólicos - aquelas áridas paisagens com as quais nos familiarizamos na poesia simbolista -; passando por personagens cínicos, amargurados, sábios e entediados; até textos que se destacam pelo absurdo, pela bizarria e morbidez; nos quais encontramos a presença de grandes temas simbolistas: a morte, o medo e o conseqüente desprazer de viver, o vazio, o tédio (esse uma referência muito freqüente nos textos), a peregrinação e a inutilidade do esforço humano de transcender essas situações e sentimentos.

No poema-em-prosa "Diálogo em frente dos espelhos" ( $D M, 3 / 08$ / 1922), aparece a figura do peregrino: "Eu vim de não sei onde, por caminhos deslumbrantes, de olhos arregalados para as coisas", revelando uma sabedoria afetada: "O tempo envelheceu o meu engano, destruiu minha exaltação, degenerando-me os sentidos" e um vazio existencial injustificado no diálogo com o espelho:

- Andaste tanto! E não trouxeste nada, nada?

- Não trouxe nem a minha sombra...

- E é desespero ou desânimo, o que sentes agora?

- É tédio, tédio infinito, tédio irremediável...

- Como tu queres mal à Felicidade! Nem sequer tu sofres, meu amigo...?

- Nem sequer eu sofro, meu amigo!

Também em "Um rei" ( $P T, 7 / 02 / 1925)$, delineia-se o personagem desiludido, cínico e entediado, esbanjando uma sabedoria milenar em tom de auto ironia:

- Oh! Não me falem das mulheres! Estou cansado esta noite. Estou soberbamente cansado... Parece que vivi muitas idades de homem, e que fadigas milenares pesam sobre a minha cabeça. Não me falem das mulheres. As mulheres passam. Somente eu não passo, eu que me contemplo através do escoamento das imagens, e estou no fundo de todos os tempos! A bem dizer, acho incômoda essa eternidade. Mas, que fazer? O espírito transforma os seus dons em instrumentos de tortura. E o meu espírito é um velho demônio.[...] Mas, não posso extravasar-me nem sufocar-me. Sendo tudo, cansei-me de tudo. O 
tédio! O tédio! Será preciso chegar até o mais alto da montanha para ver que não há nada além do tédio, que o tédio é o fim de todas as coisas? Chamem as mulheres, chamem todas as mulheres para junto do meu tédio!

Passamos ainda por textos em que as histórias e personagens, grotescas, bizarras e, algumas vezes, até mórbidas, parecem-nos absurdamente fantásticas. É o caso de "Poema do anatomista" (PT, 1/12/1923):

Apaixonei-me por uma caveira!

...A minha amante é misteriosa na sua alegria, mas, como beija! Mas, como morde!

É redonda, lisa e fria. Não sei de caveira mais fria...

...Os dentes muitos brancos, a boca muito rasgada; a boca vive a beijarme, e os dentes a morder-me. Tenho os lábios numa ferida, e os olhos num incêndio... Sinto-me apaixonado por essa caveira!

Foi uma linda mulher, essa caveira cujo o amor venceu a morte! E tão divinamente sensual que os seus ossos causam desejos!

...Vou apagar a luz, minha caveira... e possuir-te na sombra...

Além desse, outros poemas publicados em periódicos parecem guardar uma certa morbidez que lembra bem alguns textos da geração ultra-romântica de escritores como Álvares de Azevedo, ou mesmo de poetas posteriores como Alphonsus de Guimarães.

As várias colaborações de Drummond nas revistas cariocas Para Todos e Ilustração Brasileira são amostras incontestáveis da ligação do poeta com o Simbolismo e o Neo-Simbolismo e que parece ter sido cultivada amiúde pelo poeta, já que as publicações nessas revistas, entre os anos de 1922 e 1927, eram freqüentes; em certos períodos, foram regularmente semanais. Drummond, então, dividia as páginas dessas revistas cariocas com escritores, hoje, reconhecidamente penumbristas, como: Olegário Mariano, Onestaldo de Pennafort e Raul de Leoni e Álvaro Moreyra, que dirigia essas publicações.

Bastante interessante, é perceber que, simultaneamente a essas publicações esteticamente arraigadas às tradições e convenções literárias simbolistas e neo-simbolistas, encontramos textos em que o tom difere consideravelmente. É o exemplo de um poema-em-prosa sem título, publicado no $D M(3 / 08 / 1922)$ :

O acaso, fiandeiro de surpresas, permitiu-me há dias ler uma página de certo diário sentimental. 
Sou curioso; os leitores também o são. Aí vai a página, cuidadosamente transcrita, - para a curiosidade de tanta gente...

"O que se deu comigo ontem foi imprevisto, e de tal modo o foi que se transformou de delicioso em aborrecido. Na agitação de uma rua, esbarrei com a perturbadora XXX, aquela XXX que por vezes revoa no meu desejo, fazendo-o mais amargo e mais forte. Ia a um cinema. Acompanhei-a. Estava claro que não me olhou. Ela não me olha nunca... Na sala do Pathé, começa a fita, caiu qualquer coisa de suas mãos.

Apanhei essa coisa, e as nossas mãos se encontraram. A dela estava esquisitamente fria, boa, fria... Creio que me agradeceu. E, depois, na penumbra, muitas vezes me perturbou com aqueles olhos de diabo, aqueles olhos feitos não sei de que. O poeta Olegário, se os visse, diria que há neles 'um inferno a arder dentro de um paraíso'. Pois aqueles olhos me pertenceram! Seria engano? Não foi engano certamente. E até agora estou a sentir vertigem daquela mão fria, daqueles olhos estranhos e daquela cabeleira...

Quando ela se foi, não fiquei só. O tédio fez me companhia, um tédio quase raivoso, incompreensível. O grande mal do imprevisto! Isso pode ser miseravelmente banal, mas é certo. Os prazeres imprevistos torturam mais que uma cólica. Muito mais!"

O que primeiro chama a atenção é o disfarce montado pelo poeta: a transcrição de uma página de um "diário sentimental", e que parece justificar o fato do poema-em-prosa não trazer um título, concedendo uma certa veracidade à situação e, ao mesmo tempo, um caráter inusitado, já que um diário, com sua temática do cotidiano, nada tem de "nobre", como deveriam ser os temas poéticos. O poema vem confirmar isso ao abordar não um grande acontecimento, mas um simples momento, um encontro entre duas pessoas. Na verdade, um desencontro amoroso, já que a amada do eu-poético parece não retribuir o sentimento, nem mesmo conhecê-lo: "Estava claro que ela não me olhou. Ela não me olha nunca..."

$\mathrm{O}$ pequeno contato que ocorre entre os dois personagens, quando é entregue à moça algo que ela deixou cair, e suas mãos se tocam, é descrito de maneira extremamente vaga, reforçando a impressão de desencontro amoroso: o objeto apanhado não é identificado: “...caiu qualquer coisa de suas mãos" e "Apanhei essa coisa..."; o eu-poético não sabe se recebeu um agradecimento: "Creio que me agradeceu"; é ambíguo ao dizer que os olhos da moça o observaram: "Pois aqueles olhos me pertenceram! Seria engano?" Não foi engano certamente." Também a 
descrição da mulher amada é imprecisa, apenas esboçada através de três características nada esclarecedoras: "olhos estranhos feitos não sei de quê"; "mão fria", "esquisitamente fria, boa, fria..." e "daquela cabeleira". O final do poema completa a idéia que principia a narrativa do episódio e traz o tom frustrado, de não-realização que pontua todo o (des)encontro amoroso, numa referência a um "tédio quase raivoso, incompreensível", que entra em contraste com o imprevisto do acontecimento, e irrita o eupoético cansado e desiludido, uma vez que o tédio constante é perturbado pelo imprevisível. Essa alusão a um tédio incompreensível e não justificado, lembra a expressão de enfado, fadiga e degenerescência próprias dos decadentistas franceses (e, no geral, da literatura européia de transição do fim do século XIX e começo do século XX produzida por escritores que sofreram quatro anos de guerra), entre eles Anatole France, escritor bastante apreciado por Drummond e que, segundo declarações do próprio poeta, teve bastante influência sobre seu espírito.

Também outros autores citados e elogiados em artigos escritos por Drummond nesse mesmo período (como é o caso de, por exemplo, Ronald de Carvalho, Lincoln de Souza, Henrique Resende e Onestaldo de Pennafort) inscreveram-se de alguma forma na atmosfera comum ao decadentismo europeu, considerando que cultivavam a nostalgia, uma melancolia que parecia expressar, nas palavras de Bettarello, a "incapacidade de aderir ao ritmo vivo da existência" ${ }^{*}$ contemporânea, uma espécie de desolação diante do mundo e que é uma atitude espiritual diante da vida. Por isso mesmo, ainda segundo Bettarello, os crepusculares "mais observavam do que sofriam, em seu ritmo, o drama da vida". Estendendo essa afirmação, talvez possamos dizer que esse afastamento do poeta em relação à vida corrente produzia um certo tom artificial, retórico, na poesia simbolista e neo-simbolista. Daí a proliferação das convenções literárias, tão universalmente admitidas, que deram pouca margem à originalidade e a um emprego mais pessoal dos símbolos.

Em meio à produção inédita de Drummond, há bons exemplos para o que acabamos de falar. Em um deles, o poema "O esplêndido festim" ( $P T, 23 / 09 / 1922)$, há a descrição de um curioso banquete em que o prato principal a ser servido é justamente a vida, que é descrita de forma bastante sensual e desejável: "Diante deles, ao centro da mesa enorme e atulhada de cristais surgira a nudez feminina e pagã de um corpo

${ }^{4}$ BETTARELLO, 1977, p 67. 
maravilhoso!". O "prato" se oferece convidativamente: "Meus amigos, eu sou a vida! E estou nua diante de vós! E a minha nudez é como um divino convite aos vossos sentidos agrilhoados!". Ainda assim, embora enfeitiçados pela visão do maravilhoso, os convivas, que revelam uma certa morbidez, recorrentemente descritos como "pálidos, infinitamente pálidos", mantêm uma atitude passiva e contemplativa de observar o prato que se oferece: "E nenhum deles erguia o braço para levar a taça aos lábios abertos; e nenhum deles fazia o esboço de um gesto de volúpia; e nenhum deles afastava os olhos da visão extraordinária".

Em "Museu" ( $I B, 25 / 12 / 1922)$, o eu-lírico faz um relatório de diversas coisas que são guardadas por ele (dentre elas: "cartas amorosas de rompimento, duas presas de veado, violetas murchas, cinco anéis de cabelos louros..."), num "museu da vida", e se justifica: "Para as pessoas que vivem pouco intensamente, isto é, para os que se colocarem à margem, não há nada como um desses minúsculos museus, que alegram e consolam". Para ele, viver da lembrança, e, portanto, sentir de modo distanciado, é mais gratificante do que viver a emoção do momento: "Não há nada como um pequeno museu da vida, nada, nem mesmo a vida!".

Em outro poema-em-prosa, "Viver" ( $P T, 2 / 08 / 1924)$, aparece essa mesma atitude de recusa diante da vida, visível na atitude do eu-lírico de conter sistematicamente suas emoções:

Minha alma espreita ao canto dos olhos; minha alma agita-se ao fundo da garganta. Mas nem os olhos, a denunciam nem os lábios a revelam. Vou atravessando a vida com a serenidade ridícula dos fantoches, sem tristeza nem ódio, sem amargura nem êxtase. Às vezes minha alma tenta debruçar-se nos olhos mas recua, tenta subir à garganta mas detém-se. E nem lanço ao mundo o olhar de ternura e perdão, nem pronuncio a palavra de bondade. Os homens passam por mim e eu passo pelos homens. O olhar que trocamos é frio, como vaga é a saudação que balbuciamos. Às vezes qualquer coisa vai perturbar-me; qualquer coisa vai subir-me aos lábios e aos olhos, mas os olhos se fecham e os lábios disfarçam...

Essa produção inicial de Drummond, mais fortemente atrelada às estéticas simbolista e neo-simbolista, parece ser exemplo de um artificialismo que é fruto do abuso das convenções literárias. Por outro lado, podemos inferir o que repetidamente parecia chamar a atenção de Drummond e que possivelmente está por trás da adoção dessas convenções: era justamente essa melancolia, esse mal-estar presente na 
produção dos escritores que ele apreciava e parecia querer imitar em seus textos produzidos no início dos anos 20. Quem sabe esteja aí o cerne da dimensão melancólica de uma poesia cujo autor declara ter perdido o bonde e a esperança; como também a origem do bumourdrummondiano; aspectos peculiares que perpassam e definem, pelo menos em parte, a obra do poeta.

A melancolia cultivada, demonstrando um certo prazer em sentirse triste, aparece em alguns poemas. Em "Libertação" (PT, 12/01/1924), uma tristeza sem motivo toma conta do eu-lírico: "Eu estava muito triste, aquela noite, e em vão procurava nos últimos incidentes de minha vida a causa secreta da minha tristeza... A causa não aparecia"; ele, então, se entrega inteiramente a essa tristeza, revelando, ao final, uma atitude resignada: "...Procurei reagir, lutar, fazer os mil e um gestos do homem que defende a sua felicidade, mas inútil... E dei-me como pasto àquela tristeza anônima, aquela tristeza que não perdoava... Na noite linda, errava uma doçura de resignação."

Também convém observar mais de perto a forma poema-em-prosa, bastante explorada por Drummond em seus escritos desse período inicial de sua carreira: mais de sessenta poemas-em-prosa publicados entre os anos de 1921 e 1929 em jornais e revistas. Por definição, o gênero é ambíguo, uma vez que une o prosaico e o poético, e que, aliás, está expresso no nome poema-em-prosa. Por assim dizer, para um jovem escritor dos anos 20 como Drummond, esse gênero pode ter parecido bastante contemporâneo, e, com grandes probabilidades, tenha representado uma primeira revolta contra as convenções métricas estabelecidas até então, anunciando timidamente "os moldes francos e largos" da poesia modernista, promovendo a diluição da fronteira do poético e do não-poético, do cotidiano e do sublime, do literário e do jornalístico. A forma poema-em-prosa, então, parece se aproximar muito do verso-livre, o perseguido pelos poetas modernistas, se pensarmos que ambos se apresentam sob uma estrutura compósita, ambígua.

É interessante constatar como a questão da forma parece estar sempre presente em Drummond, desde sua estréia como escritor. Na crítica "O Poeta" (DM, 22/10/1922), sobre o livro Epigramas irônicos e sentimentais de Ronald de Carvalho, Drummond afirma que alguns leitores poderão achar o livro de Ronald "detestável"; e que dentre esses leitores "...estão naturalmente os que julgam que a beleza, a alegria, o sofrimento só podem ser expressos em oito, dez ou doze sílabas bem 
contadinhas ao dedo". Porém, para ele, "o sofrimento, a alegria e a beleza suportam trinta e quatro", e completa: "A religião do metro conta com alguns suspeitos: são os que não têm imaginação bastante para compreender a independência e a imensidade da Arte." O que lembra bem o que já tinha sido dito por Mário de Andrade em várias passagens de seu "Prefácio interessantíssimo", escrito em 1921.

O primeiro poema em verso de Drummond, publicado no $D M$ a 1/12/ 1922, assinado com o pseudônimo Manoel Fernandes da Rocha, vem antecedido de um interessante texto que mostra sua preocupação com a forma:

Inicia sua colaboração nessa coluna o Sr. Manoel Fernandes da Rocha, poeta a que sorriram os moldes francos e largos da nova poesia. Ele desdenha os processos que caracterizam a técnica vulgar; nada de sílabas medidas, nem de rimas, ricas ou pobres. Não raro, foge mesmo os ritmos mais comuns, produzindo versos de um sabor absolutamente selvagem.

Não lhe faremos elogios, - mesmo porque é ele mesmo quem escreve esta nota... Mas aí vai uma das suas poesias:

\section{Sê como as torres longas e finas}

As torres, longas e finas, varando o ar, parecem pensamentos ascendendo...

$\mathrm{O}$ azul envolve as torres longas, e as torres, longas e finas, parecem árvores subindo...

As torres querem meditar...

Lá - baixo, a girar e regirar, a vida tumultuosa e inútil, a vida vertiginosa e anônima cobre-se toda de poeira...

As torres finas ferem o céu, longas e indiferentes...

Sê uma torre.

Verdadeiramente o poeta iniciava sua colaboração em verso no jornal, já que, só havia publicado três poemas no $D M$, todos em prosa. 
Apesar desse poema ser alardeado como novidade na nota que o antecede, na verdade, ele pouco tem de "nova poesia". O tema é de reverência à tradição, numa alusão ao ideal simbolista: a torre-de-marfim, símbolo da aristocracia intelectual e de recusa à ação, reiteradas e reforçadas ao longo de todo o poema através de referências a um movimento sempre ascendente, que nos remete ao desejo de transcendência da poesia simbolista. Isso pode ser percebido já nos adjetivos que acompanham torre: longas e finas; e, em seguida, nos versos: “...parecem pensamentos ascendendo...”, ou “...parecem árvores subindo"; também em: "As torres querem meditar", criando um alto contraste com a "vida tumultuosa e inútil,/ a vida vertiginosa e anônima", coberta de poeira e distanciada num "Lá - baixo, a girar e regirar", em uma atitude de isolamento social, tipicamente simbolista.

Edmund Wilson, em O castelo de Axel, afirma que uma das causas principais desse afastamento dos poetas fin de siècle da vida geral de seu tempo, era o fato de que, na sociedade utilitária que fora produzida pela revolução industrial e pela ascensão da classe média, parecia não haver lugar para o poeta, o que certamente está refletido no ideal da torre-de-marfim como símbolo do isolamento social, significando, não só um retiro das coisas mundanas, como também, muitas vezes, uma incapacidade de conciliar o mundo interior do poeta com o seu exterior, que lembra bastante a atitude do gauche tão identificada com Drummond e que revela o desacerto entre o eu e o mundo.

Assim, pode-se ler "Sê como as torres..." como uma tentativa de resposta tipicamente simbolista à pergunta de qual seria a razão de ser da poesia na sociedade moderna; pergunta que aparece de forma mais sistemática desde o Romantismo, tendo cada época formulado respostas à sua maneira. O fechamento do poema: "As torres finas/ ferem o céu, longas e indiferentes...", acrescido do verso final "Sê uma torre", revela um certo esnobismo intelectual. Tanto a nota que antecede o poema quanto o próprio poema anunciam uma atitude individualista, particular, que procura escapar às emoções vulgares e mundanas.

O que há de novo no poema fica realmente por conta da forma: versos livres, brancos, que talvez venham justificar o interessante disfarce que caracteriza o pseudônimo. Um disfarce múltiplo, uma vez que a nota parece ser, inicialmente, uma apresentação do poeta por um terceiro, quando, na verdade, é o "próprio" poeta que se apresenta, mas ainda sob o disfarce do pseudônimo, Manoel Fernandes da Rocha. Um jogo de 
esconde-esconde que protege o verdadeiro autor de uma possível reação de desagrado aos versos de "sabor absolutamente selvagem". É provável que esses versos, aos olhos dos conservadores leitores do $D M$ da década de 20 , realmente tenham parecido excessivamente modernos, pelo menos no que se refere à forma.

Já em outro poema, "A beleza da vida na alegria das manhãs" ( $D M$, 28/12/1922 e PT, 8/05/1926), há uma mudança significativa em relação ao tom predominantemente melancólico que persistia nos poemas até então:

\section{A beleza da vida na alegria das manhãs}

Eu corria sobre a areia, com os pés nus.

A areia faiscava...

Na claridade da manhã, as árvores eram mais verdes e felizes

Eu corria sobre a areia com os pés nus.

Penetrava-me as veias a beleza da vida.

O sol ria no alto...

Dentro e fora de mim,

floriam ritmos desconhecidos.

Penetrava-me as veias a beleza da vida.

Era como se eu nascesse naquele dia.

A luz embriagava-me...

Tudo parecia novo,

e feito pelas mãos de um deus risonho.

Era como se eu nascesse naquele dia.

O tom, nada melancólico, realmente difere dos poemas anteriormente publicados, embora a atitude do eu-lírico de espelhar na natureza a sua interioridade indica um procedimento tradicional. Certos versos no poema expressam diretamente essa identidade entre o eu-lírico e o que o rodeia: "Dentro e fora de mim/ floriam ritmos desconhecidos", e "Penetrava-me as veias a beleza da vida", em que a sensibilidade do eu-poético fundese numa identificação quase panteísta com a natureza.

São muitos os aspectos que apontam para as estéticas simbolista e neo-simbolista que aparecem na poesia de transição para o Modernismo: o sentimento melancólico; a predileção pela penumbra, pelo crepúsculo; a sugestão ao invés da definição; o mistério; a temática do cotidiano (retirando o complexo do simples, conseguiu-se fazer com que o objeto artístico perdesse sua aura, sua dignidade, e que acabou se tornando uma 
inversão tipicamente modernista); o tom intimista. Para Bettarello, "incapaz de alcançar os tons altos", "a palavra perde a vibração do canto e se torna prosa", expressando "um sinal de cansaço, de incapacidade para grandes aspirações e de viver com profundidade uma palavra altamente humana". Esses aspectos acabaram por definir uma geração transicional de poetas que são, hoje, reconhecidos como "penumbristas" ou "crepusculares": Álvaro Moreyra, Onestaldo de Pennafort, Ronald de Carvalho, Olegário Mariano, Ribeiro Couto, Guilherme de Almeida, para citar alguns nomes. Esses mesmos aspectos, através de uma atenuação progressiva, aparecem também, como já nos referimos, em alguns poetas que se firmaram como modernistas. Caso exemplar é o de Manuel Bandeira, em seu livro de estréia, A cinza das horas. Assim, o Simbolismo pode ser considerado a origem para algumas tendências que se firmaram no Modernismo.

Para Drummond, a adesão ao Modernismo, registrado de forma crescente, principalmente nos poemas em que o poeta volta o olhar para o urbano, parece coincidir com a chegada da caravana paulista a Belo Horizonte em abril de 1924, data que marcou o início de uma grande amizade entre Drummond e Mário de Andrade, cultivada através da correspondência constante e extensa entre os dois escritores.

A partir de 1924, os poemas publicados nos jornais e revistas mostram uma ambivalência entre o tradicional e o moderno, em que o olhar do poeta passa a marcar as diferenças, a distância entre um e outro. O poema seguinte ( $D M, 14 / 10 / 1924)$ é um bom exemplo para mostrar essa ambivalência:

\section{A voz de um destino solitário}

Vesti de lírios o meu pensamento, coroei de rosas minha imaginação, e, num gesto de encantamento, adornei de pedras raras meu coração.

Imortalizei-me!

$\mathrm{E}$, imaterializando, fiquei a esperar

a graça de tua figura e teu amor.

Purifiquei-me!

Purifiquei-me todo, para gozar

d'essa infelicidade o infinito amargor.

${ }^{5}$ BETARELLO, 1977, p. 95. 
E eternamente ficarei à tua espera...

Tu não vieste. Tu não vens. Tu não virás...

Mário de Andrade, em comentário ao poema, disse: “...o poema não vale nada de nada. Meio Guilherme, meio inutilidade, meio o "não veio não virá mais' que não me lembro agora de quem é". ${ }^{6}$ As influências percebidas por Mário são de nomes reconhecidos. O "meio Guilherme" certamente se refere ao poeta Guilherme de Almeida, que se notabilizou por um virtuosismo estético e que, embora ligado ao grupo da Semana de 22, produziu uma obra poética muito mais filiada à tradição do que aos moldes liberados do Modernismo. Já a referência ao "não veio não virá mais", é bastante provável que remeta a Alberto de Oliveira, poeta parnasiano que escreveu em seu poema "Vigília": "Não veio. Não virá mais", versos que parecem ter inspirado também, além de Drummond, o poeta Olegário Mariano, que escreveu em seu poema "O aspecto mais lindo da cidade", do livro Cidade maravilhosa (1923): “- Ela virá? É bem possível/ Que não venha. Não vem.” A mesma temática do amor irrealizado, no tom crepuscular, presente em vários poemas, e que inspirou ainda tantos outros publicados na mesma época, como já vimos anteriormente.

Em 8/01/1925, também no DM, Drummond publica o seguinte poema:

\section{Serenata}

E as estrelas e os vagabundos...

Liricamente, pelas esquinas, os violões choram... Velho tema!

E sobre o casario adormecido, lentamente, vai ondulando a angústia dos violões.

Cigarras noturnas, homens tristes...

Uma janela aberta, um quadro amarelo

na noite muito azul... Os violões românticos

têm mais desejo e mais saudade

e mais amor.

Um auto passa: Fon-fon! Fon-fon!

E cada vez mais tristes, os violões...

${ }^{6}$ SANTIAGO, 2002, p. 231. 
O poema anuncia o fim de uma época em que prevaleciam os "violões românticos". Esses já aparecem no poema em franca decadência: "Liricamente, pelas esquinas,/ os violões choram... Velho tema!"; quase moribundos: "angústia dos violões"; tocados por "homens tristes". As referências a outros poetas são evidentes: o poema de Cruz e Souza, "Violões que choram", emblemático da musicalidade simbolista; e Gonçalves Dias, nos versos "...Os violões românticos/ têm mais desejo e mais saudade/ E mais amor", que evocam a "Canção do exílio": "Nosso céu tem mais estrelas,/ nossas várzeas têm mais flores,/ nossos bosques têm mais vida,/ nossa vida mais amores." O poema coloca a tradição romântica e simbolista. em colapso com a modernidade anunciada pelo automóvel que passa: "Um auto passa: Fon-fon! Fon-fon!", acentuando em seguida, no verso final, o estado de decadência expresso desde o início do poema: "E cada vez mais tristes, os violões..." (grifo nosso).

Um outro poema, presente no caderno enviado a Mário de Andrade, dialoga com a mesma tradição romântica do poema anterior:

\section{Primavera nas folhinhas e nos jardins}

O perfume das rosas entra-me no quarto numa lufada de primavera.

E eu fico desvairado a sentir o perfume o perfume das rosas pelo quarto.

Numa lufada de primavera!

Que bom ler os poetas sadios

e não saber da lua, das estrelas

e não saber do amor! e não saber de ti!

(de ti que és pálida e feia

palidamente feia e melancólica)

mas apenas sentir alucinante e forte

o perfume das rosas pelo quarto

numa lufada de primavera!

Na primeira estrofe do poema percebemos um certo deslumbramento do eu-poético, perceptível nas reiterações das palavras rosas, primavera e perfume; e no verso exclamativo em destaque, isolado. A segunda estrofe parece justificar a empolgação do eu-poético na primeira ao refutar toda uma simbologia pertencente à tradição literária que poderia estar relacionada com o motivo de seu deslumbramento. Os cinco 
primeiros versos dessa segunda estrofe contestam a tradição romântica: a referência aos "poetas sadios", como alusão e contraste aos poetas românticos, acometidos pelo "mal do século", e também como elogio à nova geração dos poetas modernistas. Também lemos a negação não só de símbolos diletos da poesia romântica: a lua e as estrelas, além da própria rosa; como também de um tema caro aos românticos: o amor; e da imagem da mulher romântica: pálida e melancólica. Enfim, o poema parece um elogio à pretensa simplicidade na linguagem e no tratamento de temas, tão apregoados pelas poéticas modernistas; a simplicidade que permitiu a Gertrude Stein afirmar que "uma rosa é uma rosa é uma rosa". Em "E o fim coroa a obra" ( $D M, 21 / 12 / 1926)$, temos um procedimento semelhante ao poema anterior, mas de caráter muito mais provocativo:

\section{E o fim coroa a obra}

Uma toada melancólica

sobe no ar melancólico

melancolicamente...

Que melancolia!

Acendei os vossos cachimbos!

Esvaziais os vossos copos!

Iluminai as vossas carrancas!

Acabou-se a poesia melancólica.

Os quatro primeiros versos do poema recriam uma espécie de clima monótono e taciturno que caracteriza a poesia penumbrista e, em certa medida, também a romântica, através da repetição exasperante dos termos cognatos: melancólico, melancólica, melancolicamente, melancolia; ao mesmo tempo que concede um tom zombeteiro pela repetição enfadonha que caracterizaria um estilo de poesia já sem recursos de sobrevivência. Os versos seguintes entram em contraste com os primeiros pelo tom festivo, e vêm para colocar um ponto final na melancolia: o eulírico, de maneira bastante provocativa, ao mesmo tempo que convida, comemora ele mesmo o fim dessa poesia melancólica. O verso "Iluminai as vossas carrancas!", é particularmente interessante como crítica à atitude austera que refletia o pessimismo e o tédio existencial da geração de escritores românticos e penumbristas. 
O poema "Cantiga da experiência" ( $D M, 8 / 05 / 1928)$ também permite uma leitura metalingüística, embora, claro, não se restrinja a ela:

\section{Cantiga da experiência}

Eu me assentei à mesa dos deuses.

Os deuses todos bebiam, sorriam, diziam coisas espirituais.

Dei de ombros e voltei à vida.

Eu dormi no leito das deusas.

Todas as deusas me abraçaram, todas me beijaram.

Dei de ombros, indiferente, e voltei à vida.

Meus pés pisaram o barro dos caminhos, minhas mãos tatearam na sombra e muitas vezes as encruzilhadas me iludiram.

Comi raízes amargas e frutos ruins, dormi sobre pedras inocentemente e vi os homens e as mulheres.

Pois a vida me embalou.

Nesse poema, parece existir uma crítica à tradição poética na atitude desdenhosa com que o poeta relaciona-se com as referências à mitologia que aparecem no texto e que podem representar essa tradição. Essa atitude desdenhosa está no gesto de dar de ombros que aparece ao final da primeira estrofe e se repete na segunda estrofe, nessa, ainda intensificada pelo "indiferente" que acompanha a expressão.

Segundo Anna Balakian, em comentário às convenções do simbolismo na literatura européia, o poeta simbolista recorreu

... à paisagem helênica como uma segunda fonte de símbolos, mas de um modo bem diferente dos parnasianos. ...Na poesia simbolista, os símbolos gregos tiveram um emprego muito mais pessoal. Como Jacques Rivière apropriadamente observou, muitos anos depois: "A Grécia dos poetas de hoje não tem nada de clássica. É uma terra de sonho aonde vão brincar com as ninfas". ${ }^{7}$ 
Realmente, em "Cantiga da experiência", a mitologia parece representar uma evasão, uma vez que o mundo representado por esses deuses e deusas citados no poema é repetidamente preterido pelo poeta através da atitude de dar de ombros e "voltar à vida". Assim, cria-se uma espécie de oposição entre "vida" e o mundo sedutor dos deuses. Assim, entendendo as referências à mitologia como alusão à tradição parnasiana e simbolista, pode-se subentender, através dos versos seguintes, que essa tradição foi também experimentada como possibilidade estética pelo poeta: "Eu me sentei à mesa dos deuses", "Eu dormi no leito das deusas", ainda que essa tradição tenha sido posteriormente descartada: "...dei de ombros, indiferente, e voltei à vida". O poeta admite ainda que "...muitas vezes as encruzilhadas me iludiram", e que "suas mãos tatearam nas sombras", provavelmente em busca da melhor forma de expressar os novos tempos e romper com a linguagem tradicional, num período de transição em que a tradição influenciou a sua poesia. Ao final do poema, as novas tendências são vitoriosas: "Pois a vida me embalou", certamente a vitória de uma concepção mais ampla e generosa da poesia estabelecida pelo Movimento Modernista, conquistada a duras penas: "Comi raízes amargas e frutos ruins", mas que também significou uma tomada de atitude mais simples diante da vida: "dormi sobre pedras inocentemente/ e vi os homens e as mulheres". O título do poema, "Cantiga da experiência", poderia se referir, então, a uma espécie de aprendizado empreendido pelo poeta.

Um outro poema, "Canção do grego desencantado", presente no caderno enviado a Mário e publicado em dois periódicos, também ilustra o diálogo entre tradição e modernidade, revelando uma crítica ao passado através da mitologia, como no poema anterior:

\section{Canção do grego desencantado}

Ó tocadoras de flauta nos doces, nos apagados

festins de Alexandria... Vós que tínheis o corpo branco como um lírio, e vos perfumáveis de nardo sândalo e verbena! Há muito que vos não ouço, há muito tempo Que reclinado no meu leito de rosas, aguardo o vosso regresso.

\footnotetext{
${ }^{7}$ BALAKIAN, 2000, p. 87.
} 
E não vindes... E canta nos meus ouvidos a saudade de vossas flautas que há tanto tempo me perturbaram... as vossas flautas harmoniosas... E se tento esquecer, fugir ao vosso fino sortilégio, vem e revém aos meus ouvidos a eterna música misteriosa.

Tocadoras de flautas, nuas, entre coxins de púrpura sob o véu dos incensários! Onde os nossos corpos de iônia espuma? E os vossos frágeis instrumentos? Onde a coroa de violetas? Há muito que me fugistes e ouço ainda a vossa música,

E há nos meus olhos a saudade infinita de vossas formas.

Vinde em teoria, cercar o meu leito desencantado

de grego triste. E modulai as mais puras canções,

e embalai o meu sono o grande sono em que vou mergulhar,

ó tocadoras de flautas, leves e perfumadas...

Esse poema, em versão publicada na revista Ilustração Brasileira e na cópia enviada a Mário de Andrade (ambas de maio de 1926), tinha como último verso: "ó tocadoras de flauta leves e perfumadas". Já na publicação do jornal DM em 1/08/1928, esse último verso aparece como: "ó tocadoras de flauta coelho-néticas". Certamente, a mudança desse verso, sugerida por Mário de Andrade e adotada por Drummond, é bastante significativa para reafirmar o poema como satírico. Mário chegou a hesitar diante do caráter sério ou não do poema; é o que percebemos pelo comentário feito ao poema, e enviado por carta: "Palavra de honra que fiquei sem saber se era sério ou sátira. Pra sátira está muito sério, pra sério está muito inútil. Mudando o último verso pra 'Ó tocadoras de flauta leves e coelhonéticas!', fica sátira de bom calibre ...” Embora a primeira versão não carregue a ironia tão explícita do verso final da segunda versão, achamos improvável que o poema tenha sido concebido como "sério" por Drummond, uma vez que o poeta já havia escrito vários poemas essencialmente modernistas, como, por exemplo, "No meio do caminho", "Sentimental", "Música" e "Igreja".

"Canção do grego desencantado", à semelhança de "Serenata", também se refere ao fim de uma época, no caso a da poesia parnasiana. No poema, temos o fim dos "apagados festins de Alexandria", pois todo o poema fala da ausência das "tocadoras de flauta"; por isso os versos que se referem a elas se encontram no passado: "Vós que tinheis o corpo branco como lírio", "e vos perfumáveis...", "vossas flautas que há tanto tempo me perturbaram...", "há muito que me fugistes..." (grifos nossos); 
o que justifica o fato do "grego" se apresentar como desencantado e triste. Os versos finais revelam a impossibilidade do regresso dessas "tocadoras de flautas leves e perfumadas", pois, em face da ausência delas, o "grego triste" escolhe também se ausentar: "...e embalai o meu sono o grande sono em que vou mergulhar".

Em 9/10/1928, Drummond publica no $D M$ o seguinte poema:

\section{Confissão}

Meus olhos coloniais namoram as velhas casas caindo.

Minhas mãos coloniais acariciam os móveis pretos carunchados.

$\mathrm{E}$ as velhas mulheres?

Meu coração colonial palpita de ternura diante das velhas mulheres de xale preto.

Porém minha roupa moderna colarinho bengala sapatos fazem de mim um boneco muito século vinte dinâmico frívolo cínico.

É preciso!

Pus antenas de rádio no meu Sabará.

O poema traz um claro embate entre tradição e modernidade, deixando transparecer uma espécie de nostalgia em relação ao passado provocada pela adaptação inevitável, forçosa aos novos tempos. A primeira estrofe fala de uma tradição em franca decadência representada pelos olhos, mãos e coração coloniais, pelos "móveis pretos carunchados", pelas "casas caindo" e pelas "velhas mulheres de xale preto", mas que suscitam no eu-lírico uma ternura confessa que faz o "coração colonial" palpitar, os "olhos coloniais" namorarem as "velhas casas", e as "mãos coloniais" acariciarem os "móveis pretos carunchados".

A segunda estrofe, introduzida pela adversativa porém, entra em franco contraste com a primeira estrofe ao descrever uma espécie de artificialidade vivenciada pelo eu-lírico, que pode ser vislumbrada através do exterior - "roupa moderna", pelo termo "boneco", ainda acentuado pelo uso dos adjetivos "dinâmico, frívolo e cínico" - e que não corresponde ao interior desse mesmo eu-lírico, regido por um "coração colonial". Embora fique evidente o descompasso entre o dentro e o fora do eu-lírico, 
que revela o embate eu x mundo, desenhando a imagem do gauche, de Carlitos ("colarinho, bengala, sapatos"), a necessidade de se adequar aos novos tempos parece inevitável: "É preciso..." O último verso do poema, "Pus antenas de rádio no meu Sabará", um tanto curioso, parece reafirmar essa espécie de necessidade de modernização já sendo assimilada pelo eu-poético.

"Confissão" parece funcionar como uma introdução para os poemas publicados no final de 1928 e no ano de 1929 (ao todo, o poeta publicou somente sete poemas nesse período), indicando um modo definitivamente novo de se fazer poesia em relação à tradição brasileira. Nesse período, Drummond publicou quatro poemas que saltam aos olhos por conjugarem poesia e cotidiano, poesia e jornalismo. Nesse sentido, esses poemas parecem apresentar uma ruptura definitiva com a linguagem tradicional, caminhando para uma renovação dos meios, para uma dessacralização da poesia, aliás, ponto forte e, ao mesmo tempo, polêmico do Modernismo Brasileiro.

O primeiro desses quatro poemas, "A grande liquidação" ( $D M, 26 /$ 10/1928), é acompanhado de uma nota dizendo ter sido extraído de anúncio publicado na Gazeta de São Paulo em 5/11/1927 por Antônio Crispim (um dos pseudônimos de Drummond). Efetivamente, à maneira de Oswald de Andrade, que no poema "Agente" parecia reproduzir um anúncio imobiliário de jornal, Drummond parece reproduzir um anúncio publicitário:

\section{A grande liquidação}

Acabou, acabou a grande liquidação

$\mathrm{Na}$ Casa dos Vestidos

E voltou a continuação

Fregueses bem servidos.

Acabou novatos, vieram novatos

Com beleza e barateza

Vestidos para visitar os Finados

Da delicada seda francesa.

Pretos, elegantes e baratos

Para aliviar a tristeza

É só na Casa dos Vestidos

À Rua da Liberdade, 86. 
A visão cética do eu-lírico do poema revela o mecanismo enganoso, a mentira, o "tem, mas acabou" da liquidação, da propaganda: "Acabou, acabou a grande liquidação", mas "...voltou a continuação". A ironia, presente na antítese novatos $\mathrm{x}$ finados na segunda estrofe, desnuda a artimanha da propaganda que se propõe a aliviar a tristeza do dia de finados com vestidos "Pretos, elegantes e baratos". É imprescindível ressaltar que o poema foi publicado pouco antes da data de dois de novembro, dia de finados.

O poema subseqüente, "1o de janeiro" ( $D M, 1 / 01 / 1929)$, reveste-se de um tom meio irônico, meio melancólico ao reconhecer a hipocrisia social, a impessoalidade e superficialidade da vida moderna, da qual o poeta se ressente:

\section{1o de janeiro}

A folhinha ingenuamente me deseja boas-festas.

Mas quem fez a folhinha nem sequer me conhece.

Não é amigo nem inimigo:

um irmão que eu tenho, embora desconhecido.

Obrigado, meu irmão de longe, meu camarada.

Estás a meu lado nesta manhã fria em que todas as coisas são novas, em que a voz do padeiro vibra como a voz do profeta anunciando o Paraíso

e as pessoas que vão pra igreja se abraçam como se todas fizessem anos.

Tomo café pensando em ti e parto contigo este bolo, tendo cuidado de te dar o pedaço maior e mais cheio de passas.

Você gosta de muito açúcar? Quem sabe se prefere café com leite?

Sem cerimônia, meu amigo.

Adeus, leva estes doces pra gurizada.

Lembranças a tua patroa. Que dia mais bonito, hem?

E até $\mathrm{o}$ ano que vem.

O poema ressalta o clima de comunhão e harmonia que caracteriza a entrada do Ano Novo. Chega a ter um tom comovido na terceira estrofe ao revelar um cuidado desmedido na refeição partilhada com o amigo, mas, já na estrofe seguinte, a comoção é disfarçada em meio às amenidades dos clichês: "Lembranças a tua patroa. Que dia mais bonito, hem?". Gradativamente o poeta vai desnudando a hipocrisia das convenções sociais, para, no último verso do poema, "E até o ano que 
vem”, mostrar que todo o clima de comunhão, de harmonia está circunscrito ao período das festas de fim de ano.

À semelhança do poema anterior, em que o tema se vincula às efemérides, Drummond publica no período de carnaval o poema "Diálogo dos burgueses no bonde" ( $D M, 10 / 02 / 1929)$ em que, numa espécie de diálogo rimado, duas pessoas debatem sobre o carnaval:

- Eu se fosse autoridade

proibia o carnaval.

Uma imoralidade!

- Peço permissão

para uma observação.

O povo tem direito de se divertir

ao menos nesses três dias passageiros.

O povo paga imposto, cavalheiro.

- Direito de se embriagar?

De cheirar lança-perfume?

De meter o pau no cobre?

E o bom-senso?

Onde fica o bom-senso, cavalheiro?

$[\ldots]$

Vale notar como esse poema difere bastante do que publicou Drummond no mesmo período de Carnaval no ano de 1925. Nesse ano, Drummond publicou no DM dois poemas: "Pierrô patológico" (20/02/ 1925) e "Último pierrô" (22/02/1925), representantes da tradicional temática do desencontro amoroso e da dor individual, sem nenhuma afinidade com o tom bem-humorado e crítico de "Diálogo dos burgueses no bonde".

Por fim, o "Poema sobre uma casa" (DM, 3/10/1929), no qual Drummond deixa uma lacuna para que sejam colocados, segundo ele, os "nomes dos aviadores famosos do dia".

\section{Poema sobre uma casa}

Minha casa é cercada de árvores.

Tem uma casuarina fina que canta de noite e sua voz é uma voz de águas distantes.

Tem um pé de ameixa trançado de erva de passarinho, tem laranjeiras, tem mangueiras, tem bananeiras.

E tem o céu largo nas janelas do fundo, 
céu virgem de aeroplanos

onde nem Santos Dumont

nem este

nem aquele (1)

nunca deram uma pirueta.

Céu que Deus fabricou especialmente para as andorinhas

e para os papagaios de papel de seda dos meninos que fogem da escola.

(1) Colocar, aqui, nomes dos aviadores famosos do dia.

O poeta parece ter aqui a consciência do modernismo ingênuo que faz a apologia do novo, já que vê o que está por trás: o velho, a repetição, a obsolescência da propaganda. O poema, se fosse publicado no jornal com a lacuna devidamente preenchida com o nome dos aviadores homenageados, estaria "na ordem do dia", mas, teríamos então apenas uma fórmula que precisaria só de alguns pequenos ajustes para estar atualizada.

O ano de 1930 marcou a transferência de Drummond do Diário de Minas para o Minas Gerais, órgão oficial do estado, em que atuou primeiramente como auxiliar de redação e, logo depois, como redator. Além ter sido também o ano de publicação de seu primeiro livro, Alguma Poesia.

O que podemos perceber, analisando mais detidamente os poemas escritos por Drummond nesse período de 1921 a 1929, antes de sua primeira aparição em livro, é efetivamente uma adesão gradual e consciente ao Modernismo. Os primeiros poemas publicados no Diário de Minas em 1921 mostraram composições fortemente influenciadas pela estética simbolista, como vimos nos poemas-em-prosa "O poema dos amantes que envelheceram com o último beijo" e "O poema da mulher que não mais se refletia no espelho". Em seguida, temos poemas em que aparecem questões formais já conflitantes com o modo tradicional de se fazer poesia no Brasil, o que é passível de se perceber nos versos livres e brancos de poemas como "Sê como as torres longas e finas" ou de "A beleza da vida na alegria da manhã"; como também é visível nos poemasem-prosa, em que a forma entrelaçada da prosa e da poesia aponta para uma revolta contra a regularidade do metro e da rima, embora o tratamento temático seja ainda condizente com estéticas passadistas.

Em momento subseqüente, tanto o tratamento formal quanto o temático parecem coincidir, e os poemas deixam transparecer a consciência da modernidade, ainda que muitas vezes ela apareça em 
conflito com um modo tradicional de se fazer poesia. Em artigo intitulado "Poesia Brasileira" (DM, 17/10/1924), Drummond mostra ter plena consciência desse momento transicional:

...estimemos no seu justo preço esses poetas de educação estrangeira, românticos ou neo-românticos (dia-a-dia importam menos as classificações), irônicos ou comovidos, ingênuos ou revoltados, que enchem de vozes harmoniosas o nosso desarmonioso momento. Não lhes peçamos mais do que podem oferecer-nos. Lembremo-nos que muitos não concluíram ainda a sua formação espiritual, no sentido rigoroso da afirmação, e, assim, não se libertaram completamente de preconceitos nocivos ou embaraçosos. Quem ousará negar-lhes modernidade? E essa modernidade está menos no feitio desatado dos poemas e no desarticulamento dos ritmos que numa concepção mais ampla e mais generosa da poesia. Esta já se mostra isenta dos grandes vícios que a torturavam até bem pouco: uma artificiosa retórica e uma desbragada eloqüência. Os nossos poetas perderam, com o preconceito da forma, o preconceito do lugar-seleto, do assunto nobre, e da compostura imperturbável. Se o Sr. Alberto de Oliveira cantava as doçuras do Olimpo, onde tronava Zeus Capitolino, o Sr. Manuel Bandeira, poeta dos humildes e dos desvairados, canta "os sapos que comem mosquitos".

Essa fase de transição foi relativamente longa e muito significativa, encobrindo os anos de 1924 e 1928, em que Drummond produziu poemas que ora se aproximavam, ora se afastavam da tradição brasileira. Essa fase culmina com uma série de poemas em tom satírico-irônico, bem ao gosto dos modernistas da primeira fase, em que a tradição é, de certa forma, ridicularizada frente aos novos valores; aqui, vimos poemas como "Serenata", "E o fim coroa a obra", "Cantiga da experiência" e "Canção do grego desencantado". Essa fase também produziu poemas que constam na obra definitiva do poeta, bastante representativos para a poesia modernista, como: "No meio do caminho", "Política", "Construção" e "Sentimental".

Como visto nas análises dos últimos poemas aqui apresentados, os anos de 1929 e 30 foram marcados por uma grande interação entre poeta e jornal. Nesse período, parece que o poeta preferiu publicar crônicas, um gênero essencialmente jornalístico. Porém essa participação pouco efetiva no terreno poético se justifica provavelmente no fato de que o poeta estaria ocupado com a finalização de seu primeiro livro, publicado em 1930. 
Esse artigo quis privilegiar parte da produção inédita em livro de Drummond, escrita até o ano de 1930, tentando delinear a inserção do poeta no Movimento Modernista Brasileiro, mas acaba por não se restringir a isso, já que essa inserção se confunde não só com a gestação do primeiro livro, Alguma Poesia, como também com parte da formação de Drummond como poeta. É o que podemos perceber pelas palavras do próprio poeta a Mário de Andrade, quando da publicação do livro de estréia, em carta de 27/04/1930:

Eis aí, Mário e amigo, a história da impressão de minha obrinha primeira. Ela aí vai... A sensação que experimento, ao ver esse livro concluído, é de alívio. Sim senhor! Que coisinha mais difícil de parir. Sinto que me libertei de alguma coisa incômoda, que me aporrinhava silenciosamente. Estou purgado de dez anos de lirismo desenfreado. Agora posso fazer outra coisa ou voltar a não fazer coisa nenhuma; de qualquer maneira, sou um cidadão impresso.

A dificuldade em extrair um livro dessa intensa e extensa produção (da qual vimos aqui uma pequena parte) está expressa na escolha da palavra que define a elaboração do livro: "parir", e o alívio ao fazê-lo não era mesmo de se estranhar, em função justamente de "dez anos de lirismo desenfreado". Dez anos que produziram um expressivo volume de poemas que passaram por uma criteriosa escolha, já que não podiam ser todos açambarcados pela publicação de Alguma Poesia. Esse título do primeiro livro de Drummond torna-se por isso bastante significativo, apontando não só para a modéstia do poeta, mas também para o fato de que o livro contém apenas "alguma" poesia de toda a produzida nesses "dez anos de lirismo desenfreado".

\section{Referências Bibliográficas}

ANDRADE, Carlos Drummond de. Poesia Completa. Rio de Janeiro: Aguilar, 2001.

BALAKIAN, Anna. O Simbolismo. São Paulo: perspectiva, 2000.

BETTARELLO, Ítalo. A poesia italiana atual. São Paulo: Faculdade de Filosofia, Letras e Ciências Humanas da Universidade de São Paulo, 1977. Boletim no 15. (Nova Série).

BRASIL, Assis. O Modernismo. Rio de Janeiro: Pallas; Brasília: INIL, 1976. 
COUTINHO. Afrânio (Org.). A literatura no Brasil. Rio de Janeiro: Livraria São José, 1959.

CURY, Maria Zilda. Horizontes modernistas; o jovem Drummond e seu grupo em papel jornal. Belo Horizonte: Autêntica, 1998.

DIÁRIO DE MINAS, Belo Horizonte (Período estudado 1920-1930 - Hemeroteca Pública de Belo Horizonte)

GLEDSON, John. Poesia e poética de Carlos Drummond de Andrade. São Paulo: Duas Cidades, 1981.

Ilustração Brasileira. Rio de Janeiro (período estudado 1920-1930 - Instituto de Estudos Brasileiros, Universidade de São Paulo).

Para Todos. Rio de Janeiro (Período estudado 1920-1930 - Biblioteca Municipal Mário de Andrade).

SANTIAGO, Silviano (Org.). Correspondência de Carlos Drummond de Andrade e Mário de Andrade. Rio de Janeiro: Bem-te-vi, 2002.

WILSON, Edmund. O castelo de Axel; estudo acerca da literatura imaginativa de 1870 - 1930. São Paulo: Cultrix, 1987.

\section{Resumo}

Esse artigo apresenta alguns textos inéditos do poeta Carlos Drummond de Andrade, escritos nos anos 20, e que atestam seu diálogo com a tradição poética, revelando-o não como um autor típico dos anos $30 \mathrm{da}$ poesia brasileira, como muitas vezes insiste a historiografia literária, mas como um poeta bastante envolvido nos combates literários e experimentações estéticas dos anos 20.

\section{Abstract}

This article presents some unpublished texts of the poet Carlos Drummond de Andrade, written in 1920's, that certify its dialogue with the poetical tradition, disclosing him not as a typical author of the 1930's of brazilian poetry, as many times insists the literary historiography, but as a really involved poet in the literary combats and aesthetic experimentations of the 1920's. 